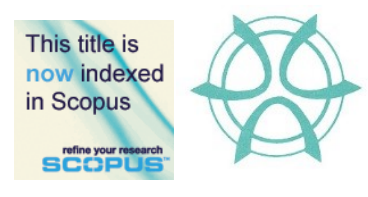

PLANNING MALAYSIA:

Journal of the Malaysian Institute of Planners

VOLUME 18 ISSUE 3 (2020), Page $14-24$

\title{
VOLUNTEERISM ACTIVITIES TOWARDS PLACE MAKING: CASE STUDY PITT STREET, PENANG
}

\author{
Muhd Nadzmi Abd Rahim ${ }^{1}$, Diana Mohamad ${ }^{2}$ \\ ${ }^{1,2}$ School of Housing, Building \& Planning \\ UNIVERSITI SAINS MALAYSIA
}

\begin{abstract}
Through the World Giving Index 2014 Survey by the Charities Aid Foundation (CAF), Malaysia is ranked 76th out of 160 countries in terms of willingness to spend time to engage in volunteerism, provide financial assistance to others and be prepared to help non-Malaysian citizens (Lili Wang \& Robert Ashcraft, 2014). Place making is a concept used in the planning, design and management of public-spaces in urban areas development; where it influences social development of a location. Volunteering activities should be determined by the type, place and time of a place where the activity is conducted. This study focuses on the UNESCO World Heritage Site in Penang (Malaysia) namely Street Pitt. Questionnaire survey was conducted in order to understand the sociability and volunteerism activity of the study area. The variables include types and frequency of volunteerism, level of involvement and factors influencing place making. The finding shows that Street Pitt manages to be one of the places that apply all elements contained in the concept of making place. In the social aspect, this area has become a popular volunteerism activity and also one of the most visited tourist spots.
\end{abstract}

Keywords: Volunteerism, Place making

2 Lecturer at Universiti Sains Malaysia. Email: diana_mohamad@usm.my 


\section{INTRODUCTION}

Willingness to undertake a service without needing to be assigned, ordered, or told can be derived as volunteerism. It is an act of taking the initiative on a task and responsibility without being requested to do so or even responses for the order. Volunteerism is an activity that is time-consuming, unpaid, doing something that aims to benefit the environment, individuals or groups other than (or in addition to) a close relative. According to Morris et. al (2013) and Jelena et al. (2018), current demographic, policy and management changes are a challenge to voluntary organisations to develop voluntary practice in their place. One of the aspects that can make society engagement more sustainable is through volunteerism. Volunteers are a powerful way to engage people in addressing development challenges where everyone can contribute for any development and betterment in social aspects and community themselves (UN Volunteers Myanmar, 2015).

Place making is a method that combines both an overarching idea and a hands-on tool. The purpose is to improve a neighborhood, city or region. The potential ideas can be used to transform the place where it can strengthen the connection between people and the places they share. Place making is one of the approaches used in the planning, design, and management of public spaces. Place making is a multi-dimensional approach of perspectives in the planning, design and management of public spaces in the area of public-space (public spaces). This approach is expected to make a built environment safe, comfortable, attractive and can be identified or associated with the community. Place making can create an environment that is capable of powering the next creatively for the community to be part of the identity of the local community. In light of this, this paper is aimed to determine the factors motivating community engagement in volunteerism activities, and the results will then be studied in order to assess its contribution to place making of Pitt Street.

\section{LITERATURE REVIEW}

\section{Volunteerism Activities}

According to Emmeline Widjaja (2010), the quote by Winston Churchill, "We make a living by what we get, but we make a life by what we give", encapsulates the meaning that people derive to helping others. The desire to help appears to be an essential aspect for everyone because it is part of human nature. One particular type of helping behaviour is volunteerism. Volunteerism activities among community themselves will empower the spirit of the neighbourhood and enhance brotherhood and awareness in appreciating and assisting society in need through the volunteering works in the community area itself. In this way, volunteers can play a major role in bringing change in society and across the country. To Clary and Snyder (1999), there are six motives influence someone to do volunteerism: 
Muhd Nadzmi Abd Rahim1, Diana Mohamad2

Volunterrism Activities Towards Place Making: Case Study Pitt Street, Penang

2 Values: 1. Refers to the expression of values related to altruistic and humanitarian concerns, 2 . Offer opportunities to meaningfully serve others

3 Understanding: 1. Motivations oriented to acquiring and/or improving knowledge, skills, experiences, etc; 2. Present professional in-service training with time for self-reflections

4 Enhancement: 1. Motivations centered on self-knowledge, selfdevelopment and, in general, feeling better about oneself, 2. Keep the experience positive and upbeat

5 Career: 1. Motivation to enhance knowledge in a specific area related to professional and academic development, 2. Provide specific skills development

6 Social: 1. Motivations related to what are called social adjustment and adaptation functions, 2. Facilitate team building and opportunities to socialize

7 Protective: 1. Motivations oriented to protecting the ego or escaping from problems.

\section{Place Making Concept}

According to Metropolitan Planning Council (2008), place making is a multi-faceted approach to planning, design and design public space management. It involves viewing, listening, and asking questions about people who live, work and play in something specific to meet their needs and aspirations. This information is then used to make the same vision for the place. Vision can grow immediately into the implementation strategy, starting with a small scale, capable of being done improvements that can benefit public space and people who use it. Creative spheres of place making bring layers to life and private space, rejuvenate structures and roads, improve the viability of local businesses and public safety, and bring various people together to celebrate, inspire, and inspire. Place making is not just the act of building or fixing up a space; it is a process that fosters the creation of vital public destinations - the kind of places where people feel a strong stake in their communities and commitment to making things better. Figure 1 shows the tool developed by Project Public Space (PPS) in order to help communities to evaluate places. 
PLANNING MALAYSIA

Journal of the Malaysia Institute of Planners (2020)

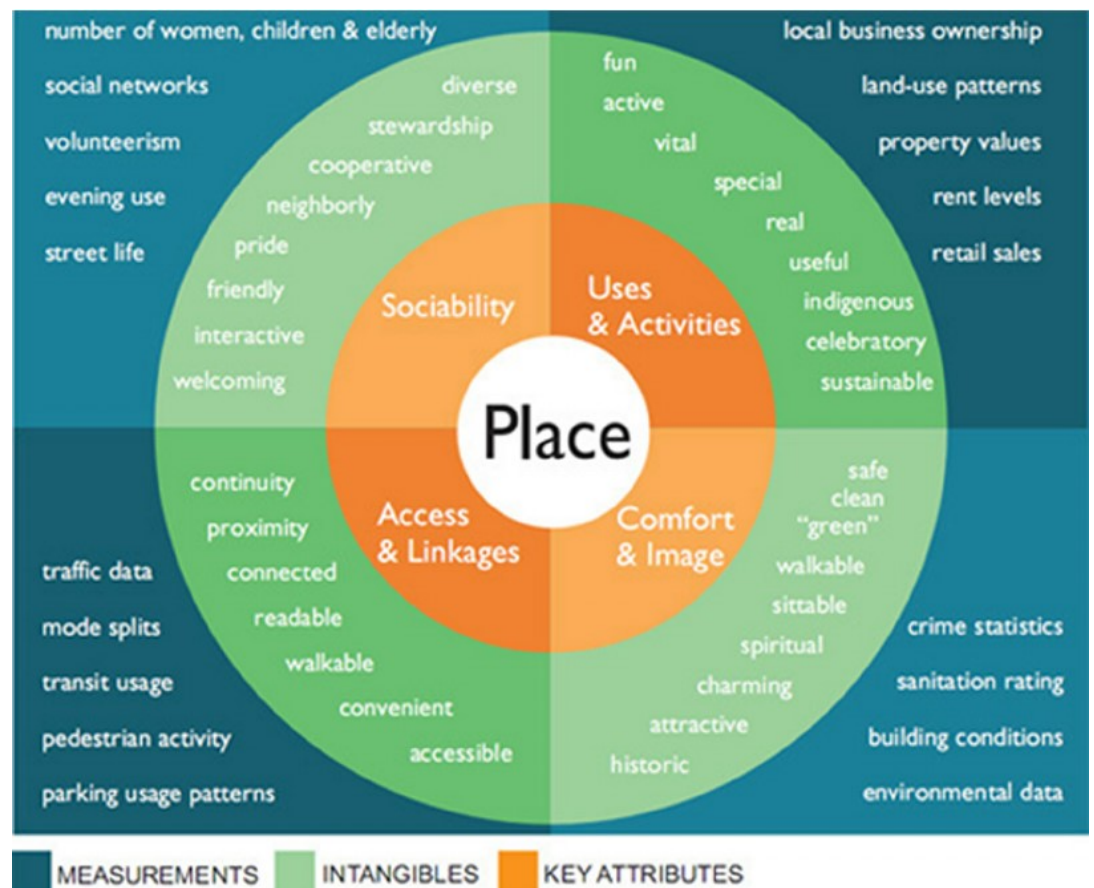

Figure 1: Developed tool for communities to evaluate places (Source: Metropolitan Planning Council, 2008)

Place making concept for place evaluation is divided into the following:

\subsubsection{Sociability:}

Sociability can be defined as the quality of being sociable and feels of liking to meet and spend time with other people. It is a pleasurable and delightful experience as a result of society interaction. Sociability is important to make a good place making, yet it is one of the hardest qualities to be achieved (Project Public Space (PPS) (Metropolitan Planning Council, 2008). Through sociability (including feeling comfortable to interact with strangers), the society tends to feel a stronger sense of place or attachment to their community and to the place that fosters these types of social activities. According to Morris et al. (2017) it can be measured in terms of type of housings, security, privacy, volunteerism, and weekend use of the park to know what a place is all about.

\subsubsection{Uses and Activities:}

Activities are defined as the action of using something for the purpose of achieving place making, while activities are defined as the condition of something happening or done. Therefore, uses and activities are to find what volunteerism 
Muhd Nadzmi Abd Rahim1, Diana Mohamad2

Volunterrism Activities Towards Place Making: Case Study Pitt Street, Penang

activities could benefit a place. Activities are the basic building blocks of any place, so having something to do gives people a reason to come to a place and to return in the future. Therefore, a good place has more activities that are on-going and people have an opportunity to participate. According to Emmeline Widjaja (2010), the ultimate success of a space is how well it is managed.

\subsubsection{Access and Linkages:}

Access is defined as how easy a space can be reached or entered, while linkages are defined as linking different entities of the same place to a different place. A good place should have the accessibility that is connected to its surroundings, both visual and physical. A good place in addition should have a high parking availability and ideally convenient public transit in order for it to become a good place making (Clary \& Snyder, 1999).

\subsubsection{Comfort and Image:}

Comfortability and image are about the feeling of people towards the place. A comfortable space presents itself well and it is obvious that a comfortable space has a good image. Comfort is defined as a sense of physical ease to carry out activities and social interaction. On the other hand, image is tangible and intangible things that represent the space (Angela et al., 2007). Comfort includes the perception of safety, cleanliness, and availability of places to gather, interact or enjoy the environment.

\section{METHODOLOGY}

In order to have a deeper understanding about the place making elements (Social quality, Uses and Activities, Access and Linkages and the comfort and image), observation approach was first employed. Based on the observation done at Pitt Street (included in the UNESCO World Heritage Site), more detailed information about volunteerism activities, participation level and the number of volunteers were obtained. Besides, data on the motivation factors influencing volunteerism activities were gained.

A total of 70 questionnaire surveys were conducted in one-month timeframe where respondents were selected using snowball sampling, as potential candidates were difficult to find due to limited information on registered volunteers that could be obtained from the appointed organizations. The questionnaire survey was utilized to gain insights on respondents' thoughts about volunteerism activities that have been conducted and their motivation to participate in the activities. This is important as ideas and thoughts can be shared given a creative place making is tailored by the ideas of the people. The questionnaire survey was designed into four sections, namely: 1) Respondent Background Information, 2) Type of Volunteering Activity, 3) Participation Level and 4) Factors Influencing Place making. Respondent's background 
information gathered information on age, gender, ethnicity, marital status, academic level and respondent's work. Volunteer motivation was measured using the Volunteer Functions Inventory (VFI) instrument developed by Clary and Snyder (1999). The VFI was built to test the individual motives of choosing to volunteer by looking at the approach to Function Theory (Katz 1960). Place making was measured by using the element in the concept of place making by PPS. Located in a UNESCO World Heritage Site, Pitt Street has many distinctive features and a variety of uniqueness and influences various elements that mirror the sense of place (cultural and arts activities, as well as heritage values in terms of living heritage and architectural styles). Known as the Street of Harmony, it contains four religious centers of worship and this is used as a symbolical image of a harmony local community (Figure 2).

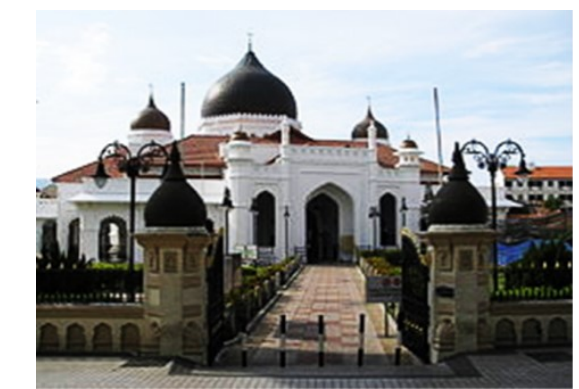

Kapitan Keling Mosque

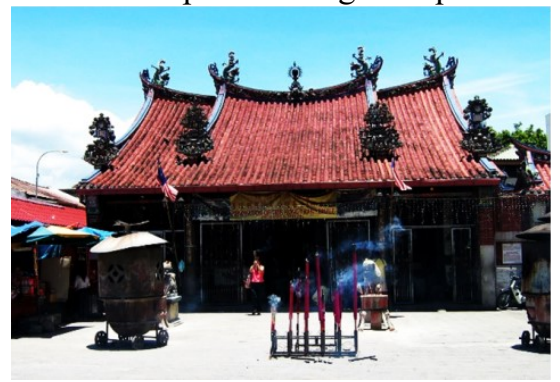

Kuan Yin Teng Temple

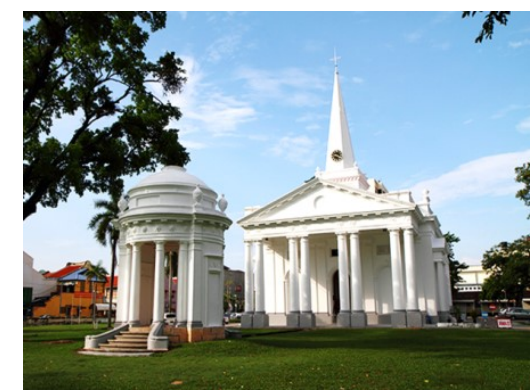

St. George Church

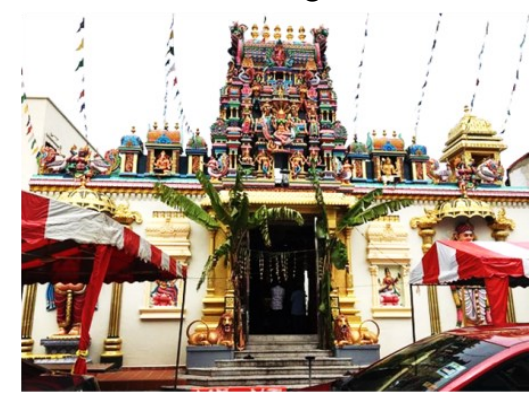

Sri Mariamman Temple

Figure 2: Religious centers of worship in Pitt Street, George Town, Penang

\section{RESULTS}

Demographic profile results are as follows: 1 . majority of the respondents were women (48 respondents, $68.6 \%$ ), 2. Most of the respondents aged between 21 to 30 years $(91.4 \%)$, 3. Majority of respondents are Malays (77.1\%), 4. 55 respondents are students (78.6\%), and 5. Most of the respondents are highly educated $(97.1 \%)$. Table 1 presents data related to the types of volunteerism 
Muhd Nadzmi Abd Rahim1, Diana Mohamad2

Volunterrism Activities Towards Place Making: Case Study Pitt Street, Penang

activities and the timing of voluntary activities. The findings show that there are nine types of voluntary activities conducted at Pitt Street. For others, the type refers to affiliations or a mixture of volunteer activities at any one time. From Table 1, it was learned that respondents were actively engaged in most of the volunteerism types $(\mathrm{M}=3.26)$. This may be due to the fact that volunteers are free to engage in any volunteer activity and most of them tend to engage in any volunteer activity available at one time. The second highest mean (3.13) was recorded for Cultural, art and Heritage volunteerism activity. This result is directly influenced by the UNESCO World Heritage Site status and most of the event and volunteerism activity conducted were related to the cultural, art and heritage aspects. It appears that morning is the most active time for volunteerism activities, compared to night time.

Table 1: Type of Volunteerism and the Activity Time

\begin{tabular}{|l|c|c|c|c|c|}
\hline \multicolumn{1}{|c|}{ Dimensions } & Morning & Afternoon & Evening & Night & Mean \\
\hline $\begin{array}{l}\text { Culture, Art and } \\
\text { Heritage }\end{array}$ & 15 & 4 & 9 & 11 & 3.13 \\
\hline $\begin{array}{l}\text { Education, Skills, } \\
\begin{array}{l}\text { Conventions, } \\
\text { Conferences and } \\
\text { Exhibitions }\end{array}\end{array}$ & 26 & 8 & 4 & 1 & 2.46 \\
\hline Health Treatment & 31 & 1 & 5 & - & 2.37 \\
\hline $\begin{array}{l}\text { Celebration of Eid } \\
\text { or Religious }\end{array}$ & 26 & 2 & 8 & 5 & 2.53 \\
\hline Natural Disaster & 20 & 7 & 7 & 2 & 2.71 \\
\hline $\begin{array}{l}\text { Sports or } \\
\text { Tournaments Event }\end{array}$ & 32 & 1 & 6 & - & 2.08 \\
\hline Tourism & 27 & 3 & 6 & 3 & 2.36 \\
\hline Community Service & 27 & 4 & 6 & 5 & 2.26 \\
\hline Environment & 31 & 3 & 6 & - & 2.21 \\
\hline Others & 15 & 2 & 13 & - & 3.26 \\
\hline Total & 250 & 35 & 70 & 27 & - \\
\hline
\end{tabular}

Table 2 presents results related to the frequency of the volunteerism activity. In relation to daily routine, the highest and the lowest frequencies were recorded for the environment (10 respondents) and sports or tournament events ( 2 respondents). In case of weekly routine, the highest and the lowest frequencies were observed for culture, art and heritage (16 respondents), and celebration of Eid or Religious and others (4 respondents respectively). Meanwhile, balance results were presented by monthly routine. For term and annual routine, it was learned that the lowest frequency displayed was 4 respondents (each for others, health treatment and tourism). 
PLANNING MALAYSIA

Journal of the Malaysia Institute of Planners (2020)

Table 2: Frequency of the Volunteerism Activity

\begin{tabular}{|l|c|c|c|c|c|}
\hline \multicolumn{1}{|c|}{ Dimensions } & Daily & Weekly & Monthly & Term & Annual \\
\hline Culture, Art and Heritage & 3 & 16 & 26 & 8 & 6 \\
\hline $\begin{array}{l}\text { Education, Skills, } \\
\text { Conventions, Conferences } \\
\text { and Exhibitions }\end{array}$ & 8 & 11 & 23 & 6 & 10 \\
\hline Health Treatment & 7 & 12 & 25 & 7 & 4 \\
\hline $\begin{array}{l}\text { Celebration of Eid or } \\
\text { Religious }\end{array}$ & 3 & 4 & 25 & 8 & 18 \\
\hline Natural Disaster & 3 & 5 & 23 & 11 & 12 \\
\hline $\begin{array}{l}\text { Sports or Tournaments } \\
\text { Event }\end{array}$ & 2 & 9 & 22 & 17 & 11 \\
\hline Tourism & 7 & 6 & 27 & 4 & 14 \\
\hline Community Service & 8 & 12 & 26 & 5 & 12 \\
\hline Environment & 10 & 11 & 26 & 6 & 5 \\
\hline Others & 6 & 4 & 20 & 9 & 4
\end{tabular}

From Table 3, level of community participation in Pitt Street was due to the community's high expectation in volunteerism activities could further improve themselves and enhance the environment. There are six involvement factors in the volunteerism activity, measured using Likert Scale. Overall, the most influential factor is related to volunteerism activity capability of enhancing noble values among society $(M=3.71)$, while the least influential factor is followed by volunteerism has a positive impact on social development and volunteerism is volunteerism has had a positive impact on the development of community integration $(\mathrm{M}=3.61)$. Results directly present the importance of volunteerism activities as foundation and fundamental to development planning and management of an area, which will positively lead to a practical and pragmatic step of place making. This study also learned that these factors influenced the involvement of local communities and volunteers to participate in all types of volunteerism activities, where this further affirms sociability element in place making concept.

Table 3: Level of Community Participation in Volunteerism Activity

\begin{tabular}{|l|c|c|c|c|c|}
\hline \multicolumn{1}{|c|}{ Level Participation } & $\begin{array}{l}\text { Strongly } \\
\text { disagree }\end{array}$ & Disagreed & Agreed & $\begin{array}{c}\text { Strongly } \\
\text { Agree }\end{array}$ & Mean \\
\hline $\begin{array}{l}\text { Volunteerism is capable of } \\
\text { enhancing noble values } \\
\text { among society }\end{array}$ & 1 & - & 17 & 52 & 3.71 \\
\hline $\begin{array}{l}\text { Volunteerism is the best } \\
\text { space to increase community }\end{array}$ & 1 & 1 & 23 & 43 & 3.63 \\
\hline
\end{tabular}


Muhd Nadzmi Abd Rahim1, Diana Mohamad2

Volunterrism Activities Towards Place Making: Case Study Pitt Street, Penang

\begin{tabular}{|l|c|c|c|c|c|}
\hline $\begin{array}{l}\text { involvement in developing } \\
\text { research areas }\end{array}$ & 1 & - & 21 & 48 & 3.66 \\
\hline $\begin{array}{l}\text { Volunteerism has a positive } \\
\text { impact on social } \\
\text { development }\end{array}$ & 1 & - & 24 & 45 & 3.61 \\
\hline $\begin{array}{l}\text { Volunteerism has had a } \\
\text { positive impact on the } \\
\text { development of community } \\
\text { integration }\end{array}$ & 1 & 1 & 23 & 43 & 3.63 \\
\hline $\begin{array}{l}\text { Volunteerism is able to } \\
\text { improve the environment of } \\
\text { an area }\end{array}$ & 1 & 1 & 19 & 49 & 3.66 \\
\hline $\begin{array}{l}\text { Volunteerism is able to } \\
\text { enhance the image of an area }\end{array}$ & & & & & \\
\hline
\end{tabular}

From Table 4, contribution factors for place making in Pitt Street was influenced by four important elements of place making concepts that are sociability, uses and activities, access and linkages and comfort and image. Classification of contributing factors consists of three categories, namely low, medium and high levels based on the mean value. The results show that the majority of respondents was influenced by the sociability element for volunteerism's ability to enhance the intimacy between local communities, volunteers and visitors with high involvement with a mean value of $3.60(\mathrm{SD}=$ 0.549 ). The second highest mean shows factors of contribution to place making is the diversity of volunteerism can enhance the image of an area which is also an element of sociability with mean value of 3.51 and SD (.503).

This study has proven that the place making of Pitt Street might be influenced by the sociability element where people desire for the integration and intimacy between local communities, volunteers and visitors / tourists. Besides, the following factors (volunteerism is able to attract a positive image, and volunteerism is able to guarantee the cleanliness of an area) are factors that also play an important role in place making of Pitt Street. The least contributing factors are as follows: volunteerism is able to enhance accessibility for information $(\mathrm{M}=3.36)$ and volunteerism facilitates a well-known and visited area $(\mathrm{M}=3.41)$. In conclusion, all factors of place making concept are well-suited for Pitt Street, which means, further research and events should prioritize Sociability elements. 
PLANNING MALAYSIA

Journal of the Malaysia Institute of Planners (2020)

Table 4: Factor of Contribution for Place Making

\begin{tabular}{|c|c|c|c|}
\hline $\begin{array}{c}\text { Place } \\
\text { Making } \\
\text { Elements } \\
\end{array}$ & Factor of Contribution for Place Making & Mean & $\begin{array}{c}\text { Std. } \\
\text { Deviation }\end{array}$ \\
\hline \multirow[t]{3}{*}{ Sociability } & $\begin{array}{l}\text { The diversity of volunteerism can enhance the } \\
\text { image of an area }\end{array}$ & 3.51 & .503 \\
\hline & $\begin{array}{l}\text { Volunteerism can make the area more } \\
\text { interactive and engaging }\end{array}$ & 3.47 & .583 \\
\hline & $\begin{array}{l}\text { Volunteerism is capable of enhancing intimacy } \\
\text { between local communities, volunteers and } \\
\text { visitors / tourists }\end{array}$ & 3.60 & .549 \\
\hline \multirow{3}{*}{$\begin{array}{l}\text { Uses and } \\
\text { activities }\end{array}$} & Volunteerism has made the area more virulent & 3.41 & .496 \\
\hline & $\begin{array}{l}\text { Volunteerism is important for the development } \\
\text { of an area }\end{array}$ & 3.40 & .575 \\
\hline & Volunteerism can be a privilege for an area & 3.44 & .528 \\
\hline \multirow[t]{3}{*}{$\begin{array}{l}\text { Access and } \\
\text { linkages }\end{array}$} & $\begin{array}{l}\text { Volunteerism is able to enhance the security of } \\
\text { an area }\end{array}$ & 3.31 & .671 \\
\hline & $\begin{array}{l}\text { Volunteerism is able to guarantee the } \\
\text { cleanliness of an area }\end{array}$ & 3.46 & .736 \\
\hline & $\begin{array}{l}\text { Volunteerism is able to attract positive image } \\
\text { for an area }\end{array}$ & 3.50 & .608 \\
\hline \multirow[t]{2}{*}{$\begin{array}{l}\text { Comfort } \\
\text { and image }\end{array}$} & $\begin{array}{l}\text { Volunteerism is able to enhance accessibility } \\
\text { for information }\end{array}$ & 3.36 & .660 \\
\hline & $\begin{array}{l}\text { Volunteerism facilitates a well-known and } \\
\text { visited area }\end{array}$ & 3.41 & .602 \\
\hline
\end{tabular}

\section{DISCUSSION AND CONCLUSION}

Pitt Street is a very well-known area for tourism attraction and social activities. Located within the UNESCO World Heritage Site, the social activities are impressive in size where the objective of these activities is related to the development of surrounding areas and the notion of strengthening the Penang State as one of the friendly areas. In addition, Pitt Street is indirectly viewed as a place of comfort that promotes social interaction and encourages loyal community and loyal visitors. To the outside world, this portrays an attractive local community that is blessed with a viable and sustainable environment for living, working and socializing. Notwithstanding these incredible features, these potential points (especially the vibrant environment and the friendly local community) are often underutilized when it comes to place making. From results, it is evident that volunteerism activities can help to improve the overall quality of life of the local community and benefits the volunteers with the ease of sociability, uses and activities, access and linkages and comfort and image of Pitt Street. Thus, in order to enliven the sense of place which is driven by residents and volunteers (which then indirectly resulted in place making), the volunteerism 
Muhd Nadzmi Abd Rahim1, Diana Mohamad2

Volunterrism Activities Towards Place Making: Case Study Pitt Street, Penang

activities and programs should use a place-making strategy that emphasizes on community-based approach and perspective. More importantly, the activities and programs should be given additional attention towards the sociability elements and these elements should be constructed on the following pillars: social, cultural, environmental and economic benefits.

\section{ACKNOWLEDGEMENT}

This article is made possible by the Fundamental Research Grant Scheme under funding of the Ministry of Higher Education [FRGS Grant No: 203 / PPBGN / 6711707].

\section{REFERENCES}

Angela Ellis Paine, Steven Howlett, Joanna Machin, Cathy McBain, Nick Ockenden, Simon Teasdale \& Meta Zimmeck (2007). Volunteering works: Volunteering and social policy. Retrieved on 18th July 2018 from http://www.kansalaisareena.fi/Vol_Works-IVR.pdf

Clary, E.G. and Snyder, M. (1999). The Motivations to Volunteer: Theoretical and Practical Considerations. Current Directions in Psychological Society 8(5), 156159

Emmeline Widjaja (2010). Motivation behind Volunteerism. Retrieved on 18th February 2019 from https://pdfs.semanticscholar.org/

Jelena Culibrk, Milan Delic, Slavica mitrovic \& Dubravko Culibrk (2018). Job satisfaction, organizational commitment and job involvement: the mediating role of job involvement. Retrieved on 18th February 2019 from https://www.ncbi.nlm.nih.gov/

Lili Wang \& Robert Ashcraft (2014). Organizational Commitment and Involvement: Explaining the Decision to Give to Associations. Nonprofit and Voluntary Sector Quarterly 43(52). https://doi.org/10.1177/0899764013515755

Metropolitan Planning Council (2008). A Guide to Neighborhood Placemaking in Chicago. PPS Publisher.

Morris, S., Wilmot, A., Hill, M., Ockenden, N., \& Payne, S. (2013). A narrative literature review of the contribution of volunteers in end-of-life care services. Palliat Med 23(5), 428-436

Morris, S., Payne, S., Ockenden, N., \& Hill, M. (2017). Hospice volunteers: bridging the gap to the community? Health Soc Care Community 25(6), 1704-1713

UN Volunteers Myanmar (2015). A study on Urban Volunteerism in Myanmar. Retrieved on 18th February 2020 from https://www.cusointernational.org/

Received: January 2020. Accepted: $14^{\text {th }}$ May 2020 